\title{
UMA LEITURA DE A MÃO DO AUTOR E A MENTE DO EDITOR, DE ROGER CHARTIER
}

Ana Elisa Ribeiro

(UFMG)

CHARTIER, Roger. A mão do autor e a mente do editor. São Paulo: Ed. UNESP, 2014

Entre os estudiosos do livro e da história do livro, no Brasil, Roger Chartier já dispensaria apresentações. O historiador francês - formado pela Sorbonne, intimamente ligado à Escola dos Annales e professor do Collège de France - é fartamente traduzido e publicado por algumas de nossas editoras, não apenas as universitárias, inclusive com livros belamente ilustrados - como é o caso de A aventura do livro - do leitor ao navegador, por exemplo. Referência comum em trabalhos de diversas áreas, como História, Comunicação, Letras e Biblioteconomia, entre outras, a obra de Chartier continua sendo incrementada em português. $A$ mão do autor e a mente do editor é mais uma das peças da obra desse autor, pela Editora da Unesp, em 2014, com tradução de George Schlesinger.

Já no Prefácio a esta edição brasileira, Chartier trata das questões da História, do fazer do historiador e da necessidade de "escutar os mortos", neste caso, escutar com os olhos, em uma poética referência aos arquivos, aos documentos, à preservação documental e à leitura como único modo de fazer essa audição e ler os vestígios de outros tempos. $\mathrm{O}$ estudo da edição e dos livros vai se ocupar, então, de uma história ligada à cultura, à leitura e à formação do campo da produção editorial, com todas as tecnologias disponíveis até hoje.

Um dos corolários mais conhecidos e defendidos de Chartier, presente em diversos de seus livros, escrito de uma forma ou de outra, aparece já neste Prefácio, qual seja: “A 'mesma' obra não é de fato a mesma quando muda sua linguagem, seu texto ou sua pontuação" (p. 11). Admitidamente inspirado em Don McKenzie, sociólogo do livro, Roger Chartier realiza, em diversos de seus livros e também neste, a exploração, a análise, a descrição e a comparação de diversas obras, principalmente literárias, em suas várias edições, ao longo do tempo. Se cada edição traz uma nova obra, é de se esperar que tanto a produção quanto a recepção se 
alterem, o que constitui sempre objeto da atenção deste pesquisador. É de se mencionar o agradecimento explícito e a homenagem que o autor faz a seus predecessores no estudo da cultura letrada e do livro que são, além de McKenzie, Henri-Jean Martin e Armando Petrucci.

A mão do autor e a mente do editor conta com 352 páginas em que se distribuem doze capítulos, além do Prefácio e de um índice remissivo. Os capítulos compõem três partes maiores, quais sejam: $\mathrm{O}$ passado no presente; O que é um livro?; e Textos e significados.

Os três primeiros capítulos abordam as questões do historiador e da leitura de vestígios em documentos, assim como as tarefas do historiador, as definições do objeto de interesse do historiador do livro, propriamente e mesmo a história dos arquivos literários e de escritores, na Europa. Como esse tipo de arquivo ou acervo é relativamente recente no Brasil, é de particular interesse saber os caminhos dessas instituições, ao longo de nosso desenvolvimento cultural, inclusive se tivermos inspirações alemãs, francesas ou espanholas para isso.

A questão que nos parece viva nestes tempos de transição ou de mudanças nas tecnologias do livro é uma das que Chartier aborda também neste volume: “O que é um livro?" Sua resposta, nem tão direta e nem tão definitiva, vai buscar subsídios em Kant, que já havia proposto, segundo Chartier, a natureza dúbia desse objeto, com sua parcela física e uma outra moral. Daí decorrem as premissas que inspiram nosso direito até hoje, isto é: a propriedade moral sobre uma obra, que será sempre do autor; e a propriedade patrimonial, que transita entre editor, autor e outros, ao longo da história da edição.

Nesse ponto, o editor é figura central, especialmente após Gutenberg. É essa figura - geralmente mal vista - que entrará em cena para editar, contrafazer, publicar, imprimir ou alterar as obras, inclusive algumas que se transformaram em clássicos universais que merecem estudo, dada a quantidade de versões e edições que acumulam. Segundo Chartier, "livros, sejam manuscritos ou impressos, sempre são resultado de múltiplas operações que supõem uma ampla variedade de decisões, técnicas e habilidades" (p. 38), e aqui podemos supor não apenas a figura do editor, mas também as de tantos outros profissionais. Também já se pode complementar a afirmação do historiador e incluir aí a edição digital, que continua sendo um trabalho de edição de múltiplas operações, aspectos mais atuais também discutidos nesta obra, embora não como tema central.

$\mathrm{O}$ autor também é objeto de discussão neste livro. A pergunta " $\mathrm{O}$ 
que é um autor?" intitula uma das seções do capítulo 1, fazendo um passeio pelas respostas filosóficas, sociológicas e históricas existentes, inclusive, é claro, as que obteve em Foucault e outros, para então chegar às propostas do próprio Roger Chartier.

A parte II de $A$ mão do autor e a mente do editor é dedicada a historiar e a ler um passado de livros, edições e reedições, especialmente no Século de Ouro da Espanha, especialidade do autor. Daí que muito se diga sobre os séculos XVI e XVII. E a parte III trará questões estruturais do livro, a exemplo dos paratextos, mas principalmente o detalhamento da história da edição das obras de Miguel de Cervantes e de Shakespeare. Os tempos de cada obra, suas refações, suas versões e sua trajetória quase indomável nos fazem tomar muito mais consciência de que os livros que conhecemos sejam, hoje, muito particulares de nosso tempo e de nossas tecnologias. O livro de Chartier que ora resenhamos nos ajuda a perceber o quão peculiar é cada ciclo de vida de cada livro escrito, editado, publicado e posto em circulação. Não à toa, um ramo da História dedicou-se especialmente a isso.

A mão do autor e a mente do editor merece ser lido com calma, com a paciência da anotação marginal, com o interesse de quem é apaixonado pela história do impresso, mas também da edição em todos os seus universos: do manuscrito ao digital. Obra de referência, ainda que repita preceitos de livros anteriores, conforme o próprio Chartier assume. De todo modo, trata-se de uma obra que nos ajuda a fundamentar os estudos do livro no Brasil, especialmente do livro literário.

Recebido em: 16 de março de 2016

Aceito em: 19 de outubro de 2016 